\title{
Motivation and Adherence of Female Junior Basketball Players in Transition to Professional Stage
}

\section{Motivácia a adherencia juniorských basketbalistek k prechodu na profesionálnu úroveň}

\author{
Katarína Šimková \\ Masaryk University, Faculty of Sport Studies, Brno, Czech Republic
}

\begin{abstract}
The purpose of the research is to discover and understand the determinants of the motivation and adherence leading female junior basketball players to continue playing game of basketball at the professional stage. The research is based on the theory of Career Transition (Alfermann \& Stambulova, 2007) and the theory of the motivational structure. The data is collected via semi-structured interviews with qualitative analysis of gathered statements. The processed data is from twelve female respondents from categories of junior and cadet (age 15-18). The preliminary results suggest that the most important aspect is communication between team members, the opportunity to progress and to improve basketball skills, sense of achievement. Another important aspect is represented through the time management, the most occurring reason for termination of the basketball career.
\end{abstract}

\begin{abstract}
Abstrakt
Cielom práce je odhalit’ a spoznat' determinanty motivácie a adherencie vedúce mládežnícke basketbalistky pokračovat'v hre basketbal na profesionálnej úrovni. Výskum je postavený na teórií Career Transition (Alfermann \& Stambulova, 2007) a teórií motivačnej štruktúry. Inštrument zberu dát predstavuje semi-štrukturovaný rozhovor s kvalitatívnou analýzou získaných vyjadrení. Spracované dáta pochádzajú od dvanástich respondentiek z kategórií hrajúcich za juniorky a kadetky (vek 15-18). Predbežné výsledky poukazujú na dôležitost' komunikácie $v$ tíme, možnost' pokroku a zlepšovat' sa v basketbalových zručnostiach, pocit úspechu („niečo" dosiahnut'). Ďalší dôležitý aspekt predstavuje time management, najčastejšie sa vyskytujúci dôvod pre ukončenie basketbalovej kariéry.
\end{abstract}

Klúčové slová: motivácia, prechod, komunikácia, pokrok, dynamika, time management

Keywords: motivation, transition, communication, improvement, dynamics, lifestyle, time management

\section{INTRODUCTION}

Junior stage can be dated approximately in adolescence, which lasts from high school until the $20^{\text {th }}$ year of life. Physical activities serve as a relaxation from tension and stress, they help to achieve certain sport performance, help find the identity. Basketball (at this stage) is one of the favorite sports, including football, ice hockey, hockey ball and table tennis (Macková, 2003).

Motivation represents basis of performance and success in sports. It relates with the experiences sportsperson lives through. The way they react toward the sport is influenced by these experiences (Duda \& Treasure, 2010). Motivational structure represents the sum of internal and external events. It isn't created randomly but generates under the influence of objective reality of life (Macák \& Hošek, 1989). Motivation is usually differentiated as internal and external. External 
motivation comes from external rewards; internal comes from within the individual. Internal motives are joy of sports, entertainment, love of action and the ability to demonstrate and improve the skills. External motives may be in the form of trophies, prizes, praise, or status (Jarvis, 2006). Internal motives are in relation with positive thinking and belief to achieve something more; these sportspeople think in a self-efficacy way. Self-efficacy is defined as an estimate of one's own abilities to successfully perform a specific task and is positively linked with motivational patterns (Macák \& Hošek, 1989).

Most people attributed the success of basketball player Michael Jordan to his remarkable ability. We cannot underestimate his need for extremely high performance. His competitive enthusiasm and zeal were legendary. That is the reason why he is seen as one of the hardest working athletes in professional sports (Weiten, 2007). His achievements could not happen without significant amount of passion. Passion is formed and developed via selection, evaluation of activities and internalization of specific activity into the individuals' identity. Autonomous internalization occurs when the individual accepted selected activity as important without any other context. Controlled internalization occurs when the activity is associated and linked with something more, such as social acceptance, self-esteem or sense of excitement. It is therefore proposed that passion is composed of harmonious and obsessive dimension (Vallerand et al., 2003). Harmonious passion is predictor of championship goals, sportspeople don't prefer sports over other aspects of their lives. Elite performance is achieved through obsessive passion of athletes who focus exclusively on their sport at the cost of other aspects of life (Vallerand et al, 2008).

Adherence is a term which means "loyalty", persistence of participant in selected program activities. It occurs mainly in operations that are result of free choice. For adherence is important its' efficacy and social support, interpersonal relationships, whether in a positive or negative sense (Slepička \& Hošek \& Hátlová, 2009). The sportsperson is consciously "faithful” to the prepared program of training in order to gain maximum benefits based on his efforts (Cashmore, 2008). The adherence is connected to the devotion. Athletes who are more committed to their training program and sport will last for a long time despite the different variables that might interfere and enter into the program (Lukwu \& Luján, 2011). Known correlates of physical activity in relation to adherence can be categorized as past and present personality attributes; past and present environment and the actual physical activity (Buckworth \& Dishman, 2007). Only a small handful of athletes achieve sporting excellence and have a successful athletic career (Stambulova \& Hanin, 2004). Research demonstrated that athletes playing the basketball are identified with sports stronger than swimmers (Stadden, 2007).

Sports career includes several components: the length of engagement in sports activity, sports that are practiced at the level of specialization and acquired sports titles, records and results. This includes benefits of sporting activities but also losses that are associated with it (time, energy, health, money), as well as satisfaction with career and career success.

Career Transition theory focuses on different stages of professional career in sports. Transition itself is an event or nonevent that results in a change in assumptions about one self and the world and thus requires a corresponding change in a behavior. Sportspersons have to cope with specific demands of change (practice, competition, communication, and lifestyle). The stages are as follow: 1. PREPARATORY STAGE; expansion of movement. 2. BEGINNING OF SPORT SPECIALIZATION or initiation stage (Salmela, $1994 \&$ Bloom, 1985); sport is more of a game. 3. INTENSIVE TRAINING IN CHOSEN SPORT or specializing years (Cote, 1999) / development stage; focus is on 2 or 3 sports they are committed to. 4. CULMINATION STAGE or the perfection stage / investment years; sportspersons become experts in their sport. 5. FINAL STAGE or maintenance years; preparation for termination. Others describe final stage as discontinuation (Wylleman \& Lavallee, 2004) or recreational years. Athletes stop participating in high level of sport; they may 
continue training for recreational purposes. The specific transitions are described as: 1. beginning the sport specialization; 2 . the transition to more intensive training in chosen sport; 3 . the transition from junior to senior/high-achievement sport; 4 . the transition from amateur to professional sport; 5 . the transition from culmination to final stage; 6 . athletic retirement.

Our participants are at the third stage (junior basketball players): developmental stage, specialization years, intensive training in the chosen sport (Alfermann \& Stambulova, 2007). As can be seen, there are many models describing stages of sports career and all of them conclude into one model of motivational structure.

The 4 stages of motivational structure, similar to the stages of development of sports career, as mentioned before, called Career Transition Theory. 1 . The phase of first expansion of the movement (biological motives, the need to move, have positive arousal; role models in parents, other sportspeople); 2 . The choice of self-assertion (social enforcement, perceived performance, positive feelings in relation to winning); 3. Sports mastery (motivational structure is clearly differentiated, personal achievement, prestige, economical advantages, sport is purposeful activity); 4. Involution of motivational structure (involution of elite performance, social-psychological problems because of retiring from spotlight, change in economical status). Every stage is full of external and internal influences that are intertwined. Together they create personality of sporting individual, his system of values, characteristics and structure of sports motivation (Votík, 2011).

The aim of the study is to elaborate the Career Transition theory with focus on enlarging the second stage (the choice of self-assertion). The intention is to draw up the Career Transition theory as a whole through other researches and projects (with orientation on different stages of professional sports career). Our main research question is about describing determinants of motivation in junior basketball players (with this article focusing on girls).

\section{METHODS}

Participants were females between ages of 15 and 18, playing basketball on the junior level. All of them are at the stages of deciding whether to continue professionally or not. They were chosen purposefully with other recommendations from participants. The total number of participants is 12. They are from Slovakia ( 5 basketball cities for female junior players - Banská Bystrica, Stará Turá, Nitra, Prievidza, Košice).

The used research strategy was qualitative approach with data collected via semi-structured interviews. Those were conducted after the agreement on the date and time with chosen participants. The interviews were recorded as the audio with informed consent (either agreed and recorded upon before the start of the interview, or signed on paper). Every interview was anonymous with a choice to stop, if interviewer would not act as professional and overstepped boundaries of the research ethics. Questions themselves were created according to the Career Transition theory with focus on the whole career - from start of their basketball career until current situation and their perspective on the future in professional and even recreational sport. The gathered interviews were put in a transcript. The data were analyzed in a Grounded Theory approach (Strauss \& Corbin, 1999) of a qualitative research design. At first, every relevant statement was assigned a code (the meaning of a statement). Second, all of the codes were put in a categories and subcategories of similar context. This process represents the first step, called open coding, followed by second step - axial coding. The codes are analyzed further by making connections between categories and subcategories. Those are put in a paradigm that involves - conditions, context, action / interactional strategies, consequences. 
Placing of the individual categories of the paradigm has shown the importance, strength and intensity of the individual elements (verified and revised by the rest of the analysis). The main concepts were selected through thematic and latent analysis.

Thematic is about working with information from the text itself, latent approach follows indirect statement, looking for anything beyond of what has been said (Braun \& Clarke, 2006).

The third step is known as selective coding. The individual categories and paradigm become connected with the core of the topic, in this case motivation and adherence of young basketball players. Selective coding allows creation of the story that reveals the periodicity in the data that verifies the detected relationships, grounds detected connection. It is important for the grounded theory that the chosen paradigm makes sense, all of the analyzed data fits naturally. If this does not happen, there is an error within the open coding. The researcher has to start all over and rethink the approach and codes itself. This situation didn't occur with the data from this research. These represent determinants of motivation and adherence of junior female basketball players.

\section{RESULTS}

The main categories expressing motivation in continuing with professional basketball career are similar in strength of the statements - all of them are interconnected (the order is based on the reoccurrence specific codes and categories). The resulting determinants are based on the paradigm and selective coding that is described in the previous chapter.

FIRST CATEGORY: Team (sociability), not being alone in such tough environment (physically and mentally). They can always rely on team members for support that is usually expressed through speeches (shouting in the game, reminding the importance of every team member, helping each other with the lack of success, physical exhibition - high fives, handshakes, rituals; and believing in each other even in the hardest times. This happens if they have open and honest communication. Every team member should be able to express their feelings, opinions, they should argue if the situation needs it. No one should be excluded and if that happens, they need to understand the reasons behind it. The relationships play other important part of their game play - on court but also outside of basketball. There is no need being best friends in personal life, but they have to understand each other and accept, tolerate each other as players and individuals. All of this creates team spirit that makes playing basketball and dealing with its demands a little bit easier.

\section{Statements of participants on team (sociability)}

P6: Well, I enjoy collective sports, so when I participated in dancing, I couldn't find myself in that, it was... I didn't enjoy it as much.

P4: I think that the team, it weighted in, I needed to be between people. It's not just about the individual sports, but I needed to be with someone, otherwise I did not enjoy it.

P9: The team we have at the moment and I guess that's all.

P1: It is so... I don't know, I cannot imagine individual sport. I like people, collective, if you are not able to do something for now, you have people around you who will support you.

\section{SUBCATEGORIES}

\section{Statements of participants on Communication}

P10: Mainly reliance on each other and tell everything right there, eye to eye.

P5: Talking about it, that it helps me to solve the situation.

P8: So we are able to speak up about things that we do wrong, not to be shy talk to each other about this. 


\section{Statements of participants on Relationships}

P9: That we understand each other, as girls we can talk about anything about private lives, that we go out together.

P3: That we can support each other on the court. It works between us even outside of the court, we are friends, we trust each other everywhere.

P7: Teammates for sure, we are great group, we come to the training session, talk, after we go out together, even at the holidays.

\section{Statements of participants on Support}

P11: Girls motivated me, that I am one of the best in the team and with me quitting, they would start losing, which is not true.

P3: Especially to support, in basketball it is important to support each other in the game, even if it is tough, when we are disappointed, there is someone who can take us further, as I can.

P9: We always try to help each other even at the training sessions when coach gives us certain exercises, we always try to help each other.

\section{Statements of participants on Team spirit}

P6: Because it is a team sport, it's about all of us and that team spirit has to be there.

SECOND CATEGORY: Lifestyle. Basketball and rigorous movement became the staple of participants' lives. They cannot imagine doing something else, to stop doing sports in general. It became strong part of their being and even if they don't want to go and train or they feel tired, want to take a break, they go and train anyway. If they decide not to go, they are usually bored and they don't feel mentally satisfied. This lifestyle is possible thanks to enjoyment from playing basketball, which was created throughout the years of playing, growing up and family lifestyle. Sport in general provides place for break from school and personal problems. They feel physically exhausted, but mentally and emotionally relaxed.

\section{Statements of participants on Lifestyle}

P10: I got used to it, it's a habit. As everyone has to go to school, I have also a basketball, I enjoy it. P9: When I go to session, then it's okay, I am used to being there all the time, so it's fine.

P3: What else would I actually do? I am doing this since childhood, I am connected to it, I have to go, not have to, it is my free will.

\section{SUBCATEGORIES}

\section{Statements of participants on Enjoyment}

P5: I think I mainly enjoyed it.

P6: It fulfills me, so that is my main thing, I enjoy it so much.

P3: I stayed with the sport because I found out that basketball is something that fulfills me.

\section{Statements of participants on Mental relaxation}

P3: It gives me not only physically but also mentally for sure. It's my different world when I am on the court and play, I don't register the reality and problems, I simply focus on myself and I am trying to motivate myself.

P6: I would rather go, especially when I don't feel well, inside stress, I go because I know I will abreact myself.

P4: It doesn't have anything to do with school, there are different themes, I can forget about school for a while, that everyday routine. 
THIRD CATEGORY: Sense of achievement. Professional basketball gives our participants opportunities to achieve something more, to show themselves and others they are doing something great, that their work is not in vain. If it transforms into winning big matches, or at least beating best of the best, they see perspective to go further. That happens through perceived self-competence. They see what they achieved in the past years and it helps them believe they can achieve more on a professional level. If they train enough, they improve their basketball skills, hear and feel praise from other people (family, fans, coach and other people working in sports).

\section{Statements of participants on Sense of Achievement}

P5: On the other side, I want to go if it will have sense, I know I can achieve something with this.

P8: The main motivation these days is to get somewhere to represent and achieve something, at least for myself.

P2: So I can be good as them, that in time I can achieve something, that I am not only junior as it was before.

\section{SUBCATEGORIES}

\section{Statements of participants on Self-Competence}

P8: I outrun myself with getting better.

P2: Then I have such a god feeling that I was able to finish it.

P6: I am trying to give it everything; it is unbelievable feeling for me to give it all of myself and knowing I did that.

\section{Statements of participants on Improvement of Basketball Skills}

P2: That I can always perfect myself, now we fight for 5th place so that is that.

P6: And when I go, I give it all I have and can, that I got better, I am able to do something new that I could not before.

P7: The will to improve myself, see the improvement.

FOURTH CATEGORY: Specifics of Basketball as a team sport and game itself. It's not boring but full of different actions, tactics of individuals and a whole team, there are always lots of dynamics. The complexity comes from requirements in physical and mental strength and most of the time intelligence. Basketball is considered being an intelligent sport especially because of the complexity, dynamics, being able to read opponents' team, not just their own team members. Other side of basketball is being active (ideal for hyperactive individuals - who our participants claim to be), which provides health that will stay with the players even after the professional career. Basketball is always interesting as an active play, but also as a passive game.

\section{Statements of participants on Dynamics}

P6: It's fast and full of action and I am full of action and I enjoy that

P11: And the basketball is fast game.

\section{Statements of participants on Complexity}

P1: I was very hyperactive child that could not sit down, so my parents needed to have me to vent out somewhere and sport is the right choice.

P6: I am very lively person, when we ended, I told myself I won't stay at home.

\section{Statements of participants on Being Active}

P3: I have done nothing whole year, I was bored at home so I had to change it.

P9: Yes, for sure, because I am bored at home, just to sit or whatever 


\section{Statements of participants on Health}

P7: Body suffers, I think, if we don't move.

P8: Disadvantages for sure that I am 15 and I can't walk the hill, my knees hurt, so health problems. Otherwise I don't see any disadvantages. We have some activity, we are not goofing around, we do something besides the school.

P3: It's good for health, for sure.

FIFTH CATEGORY: Coach is one of the vital elements for our participants in many different ways. Most of the influence comes from the first training sessions of participants, but the most significant components are seen in junior stage of basketball career as well. Coach and player should be able to develop dual relationship, which means having a work relationship on a court, little bit of personal relationship outside of the court. Coach should be able to listen to personal problems of players, try to help them, be their support as a person, someone who represents the "other parent". This type of relationship cannot exist without "game and human components". Even though basketball is a team sport, coach needs to see and work with his players as one unit but also as individuals. They should be able to teach something new all the time; every coach must bring something new. That is the way how players won't stagnate. All of this is heavily influence by the mental stability of coach. There cannot be mood swings, otherwise the training sessions and subsequently matches, are visibly poor with missing team chemistry and atmosphere. Support from coach is as important as support from other team members, which is the result of character. Coach must have an authority (through experience, stable mood, support) and respect (through fulfilling training sessions and ability to communicate, be part of the team).

\section{Statements of participants on Dual Relationship}

P4: At the training session, he should be tough, outside of the session we can talk about anything, school, friends.

P5: He should be caring, to be able to establish relationship with the players, to understand each other well, but there have to be boundaries what the player can and cannot do, to have the respect towards each other.

P6: When I was sad, crying, she took me away, wiped off my tears and that helped me so much, that it's okay I am not doing well right now.

\section{Statements of participants on Teaching something new (Game Components)}

P7: We can see if the coach doesn't want to work, we have a feeling we also don't have to, but if he's dedicated, it motivates us, he must want it also.

P9: I am very satisfied with our current coach, he is able to teach us everything, to motivate us, you hold on and go.

\section{Statements of participants on Individual Approach (Game Components)}

P8: So he will point out things I am doing wrong but also to point out things I a doing well, if he is always negative, I don't want to play.

P10: We have a very good coach now, he is strict but he is taking me forward, always gives me something.

\section{Statements of participants on Support and motivation (Human Components)}

P8: There were times exchanging with good times, we started winning and he praised me for certain things.

P3: Coach is great, he said I won't kick you out, he is so sweet.

P10: So he also is part of a team, will chant for us, praise us that it's okay, we can do it. 


\section{Statements of participants on Stable mood (Human Components)}

P6: He was a moody a lot.

P8: He was very temperamental, that is the biggest thing. He gets angry and then it influences the whole team.

Statements of participants on Character (respect and authority)

P10: To shout at us if we are doing something wrong..

P7: Sometimes he shouts as us, then he starts to laugh.

P8: You have to do it and he's done talking; you must push yourself and improve.

P4: It's about the respect, if he is late or says something and then goes the other way.

P11: Coach took us out of the game and let the others do the work.

SIXTH CATEGORY: Earn living (sustainability). Basketball represents passion that leads our participant to want (or at least think about) to continue playing on a professional level. This dream can happen only if they will be able to earn enough living not only for themselves, but also their nuclear and future families. They believe that with a good basketball club (either in Slovakia, Czech Republic or in other countries, especially Europe), they might achieve that dream.

\section{Statements of participants on Earning a living}

P10: That it may sustain my living one day if I sacrifice today, I may be better in the future, in the team with good pay.

P1: If I will play at the higher level, I could have finances to sustain me.

P2: If it was on the higher level I might earn living and be better and do something I enjoy.

SEVENTH CATEGORY: Atmosphere. This category is conclusion of everything that was mentioned until now. Basketball court is full of special atmosphere that is the result of team work, coaches' approach, dynamics of basketball, experiencing different world, becoming someone else for a little while.

\section{Statements of participants on Atmosphere}

P6: I enjoy it, the atmosphere. Atmosphere of the people, chanting from friends...

P2: Everyone wants to feel good on the court, when we create certain actions, support towards each other if we get in the bad mood.

P7: When we win, we yell and feel so good.

P10: It's a lot better game, we were losing the last game but we never stopped supporting ourselves, we played in a good mood.

EIGHTH CATEGORY - NEGATIVES: The main reason for voluntarily discontinuing career in professional basketball is time management. There is significant amount of statements focused on balance of free time, chance for developing dual career (having time for studies), have enough time for family and friends. Time management is in tight relationship with their current situation (high school, making big choices for their future). It showed its significance not only thematically but also latently.

\section{Statements of participants on Time Management}

P11: For sure, I wanted to go on school trips many times but it's not possible, if you want to achieve something, you have to train.

P8: Maybe because of the school, I don't have time. 
P9: Now I prefer school before basketball, I don't want to train and then learn late at night.

P10: I am surely annoyed that I cannot go with them, but after matches I can meet with them, usually. P3: I would leave family, friends, new start, team...

\section{DISCUSSION}

Motivation to continue playing professional sports is a theme that was, is and will be talked about and researched for a long time. That is the reason we chose qualitative research with strategy of Grounded theory by Strauss and Corbin (1999) and semi-structured interview as an instrument for gathering data. After analysis, we realized there is a lot more than just similar themes and categories. One of the significant aspects are certain "connecting tissues" that go though described categories as a "thread". No matter what the participants were talking about, there is always an importance of basketball as a team play, social game that helps them communicate and understand people better not only in their sport life, also in personal life. As mentioned before, basketball is also very dynamic game. Participants love well done game actions, great teamwork and always different training sessions. Dynamics is something that made them fall in love with the basketball, they don't follow the ball blindly, but with a purpose, certain way of thinking and it allows them to use a bit of unrestricting creativity. In result of this all, they perceive certain self-competence from the day they started doing sports, through their first matches, first wins and even losses. Now they see what they achieved and what can be ahead of them if they work hard. These aspects conclude in the main theme that is lifestyle. It was hard for our participants to express exactly what motivates them today. The only thing they were able to point to is lifestyle, basketball being part of their lives, part of their identity. We could feel it through the passion heard in their voice, seen in their gestures and their eyes. Even ones that are thinking about quitting the professional career are hesitating, because they cannot imagine living without basketball and the lifestyle it brings. Not only in playing sports but also having different purpose than their peers (they perceive them either as drinkers, smokers, partying late at night or not moving at all - sitting behind the computer all day).

Two not surprising categories bring together an interesting dimension of motivation - team and coach. Even though they are significantly important, they don't pose a direct threat to participants basketball career. They wouldn't end their careers because of some big argument, misunderstanding within the team or even very unprofessional coach. Players have put a lot of hard work and sacrifices to get to the position where they are now. The problem comes when there are too many problems between players and their team mates or coach. It can slowly destroy their enjoyment of playing basketball; they might lose passion and their love for the game. If they are lucky, they might overcome it by looking for another club. On the other hand, if they find passion for something else while there is no enjoyment for sports, that's when the thoughts about quitting may come. We can say that the team and coach are not the main reason for quitting or even continuing with sports at the junior stage. Quitting basketball because of those two aspects are a result of "snowballing", accumulation of many other smaller problems. Even then we cannot be hundred percent sure about the reaction of players; they themselves aren't at this stage sure. They are still looking for something to hold onto, because they don't want to experience regret. Only one participant did quit sports because of team and this was her statement: "I regret that I left because I know I could have gone further, even other people remind me of that, as I see how far the other girls have got."

For now we can see differences in between internal and external motivation that can be sorted out as following. External are certainly vision of paycheck that might be very good not only while having a professional basketball career but also after terminating the career. Other external mo- 
tives are prizes, especially because of the following praise from family members, friends and fans. That can be understood as a part of the internal motivation. Praise for their performance gives them great feeling of accomplishment and hope for achieving even more in the future (sense of achievement). Internal motives that play the biggest role are enjoyment and entertainment, support and great social relationships with team mates and coach, love of action (Jarvis, 2006). Ryan et al. (1997) mention that women are more focused on external orientation in sport appearance, fitness, because they are more interested in body-image than men. That doesn't appear as true, there were only two women that mentioned it. Both of them connected it more towards the overall health. This research is part of dissertation thesis with semi-structured interviews also done with boys. Their statements were very similar when it comes to the appearance (even more so).

It would be very brave to make a strict decision about which type of motivation prevail at this age. I am not confident enough to make such a big assumption. Young players are drawn towards the basketball by the happiness they feel while playing, performance enhancement, achievements of set goals, and feeling of sense - possibilities of self-realization. This, however, requires some recognition from the outside, especially in the current situation - praise, encouragement, prizes, awards - they confirm achievements players reached. External and internal motivations are connected through the performance and the need to show it off. Being able to win a match with poor performance means nothing. On the other hand, loss with a high performance is very satisfactory. They can learn from it, build on what they know already. That's when they can improve again. With the improvement comes need to demonstrate to others what they have learned. They want to prove to their spectators, coaches, family, but also the team members that their hard work has meaning. The reaction of other people (and outwards manifestation - joy, pride and admiration), helps players themselves see the meaning in basketball. They do not forget about the future and importance of wage earning. Players realize they need to earn enough money to support themselves and their potential families. That is the reason for thinking a lot about education.

As we mentioned before, there is a risk of losing enjoyment of basketball that can turn into dislike. If these players won't be able to find the love again (or even passion for anything else in life), they might experience burn-out. Past experiences and memories have great influence on the present because there are many complicated events, as in any other job, which might influence the burn-out (Eklund \& Cresswell 2007). It is described as psychological, emotional and physical exhaustion from formally enjoyable sport towards too much stress (Cashmore 2008). Burn-out is connected with the intensity of sporting activity. Young athlete must be focused on his whole ego, success in sport and other aspects of social life are put on hold (Coakley, 2007). We mentioned this in the results about the biggest reason for quitting sports - time management, not enough time for school and family.

Enjoyment of the game and success has been mentioned within differences and similarities between internal and external motivation. The results mentioned the importance of the various links between different determinants which is also applied here. If a player loses enthusiasm (reoccurring conflicts, decreasing/stalling performance, inadequate conditions, problems with the education), there is disappointment, certain loss of sense in life. They sacrifice a lot so they can play basketball professionally. There are expectations that it will be reciprocated without coercion and feelings of resistance, almost disgust. Therefore, a significant role is played by the passion.

Our participants show great amount of harmonious passion with controlled internalization (Vallerand et al., 2003). Their activity is connected with feelings of joy, absorption in sport (intensive focus on present moment, intertwined action and consciousness, loss of self-reflection, being on top of the situation, loss of sense of time, internal enrichment), which is called flow (Csikszentmihalyi, 1990). It's not meant to be as exact as we know it. Such a thing cannot be achieved on the court every time they play. It is about living another life while the game is played, as if the player could experience its own existence within different set of rules. 
Their love for basketball is strong but they need to be in harmony with other aspects of their lives, especially school (Vallerand et al, 2008). They see education as very important, even though they desire to continue basketball professionally. Participants understand risks of profession in sports, especially with injuries. Basketball represents a sense or a meaning where players can take "refuge", because of their experiences - enthusiasm, passion; especially place where to achieve the goals they set for themselves with a potential to continue with new goals as professional basketball players. If the involuntary termination of their career happens, it can bring on existential crisis, when young players don't know where to go next. Therefore, it is equally important to find the enthusiasm in other activities that may bring different meaning and sense to life, in which they will be able to "dive in".

These results and interpretation are part of the bigger research, so we decided not to include any recommendations, only our desired goals. We would love to gain understanding for continuing in such a tough and demanding profession (especially the basis of passion that is underlying theme of motivation), to obtain better understanding of youth playing sports in general. We see that it is not only important in the age range of 15-18 but also for the past, present and future (termination of their career). If we are able to understand sportspersons at every phase of their lives we might be able to help them a little bit more at any stage of their careers and even after them.

\section{CONCLUSION}

We can conclude that our first findings result in seven categories influencing the passion for continuing to an elite level of sports, senior stage. Those are basketball as a team play (social game) and its subcategories - support, communication, team spirit and relationships; lifestyle enjoyment and mental relaxation; sense of achievement - improvement of basketball skills and self-competence; specifics of basketball - dynamics, complexity, being active, health; coach dual relationship (on professional and personal), character, support and motivation, individual approach, teaching something new, stable mood; earn living; atmosphere. The last category represents the main reason for discontinuing professional sports - time management (having opportunities for studies and family and friend). The study provides strong link between motivation and passion, not only for basketball or sports in general. There is significant amount of need for passion (that seems to be strongest especially in sports), that is why some of the participants are hesitant about quitting - they need passion that is part of their identity, which is sometimes very hard to find outside of the basketball.

\section{References}

Alfermann, D. \& Stambulova, N. (2007). Career Transitions and Career Termination. In G. TENENBAUM \& R. EKLUND (Eds.) Handbook of sport psychology (712-733). New Jersey: John Wiley \& Sons.

Bloom, B. S. (1985) Developing Talent in Young People. New York: Ballantine Books.

Braun, V. \& Clarke, V. (2006). Using Thematic Analysis in Psychology. Qualitative Research in Psychology. 3(2), 77-101.

Buckworth, J. \& Dishman, R. K. (2007). Exercise Adherence. In G. TENENBAUM \& R. EKLUND (Eds.) Handbook of sport psychology (509-536). New Jersey: John Wiley \& Sons.

Cashmore, E. (2008). Sport and Exercise Psychology. The Key Concepts. Oxon: Routledge.

Cote, J. (1999). The Influence of the Family in the Development of Talent in Sport. The Sport Psychologist. 13 (4), 395-417.

Csikszentmihalyi, M. (1990). Flow: The Psychology of Optimal Experience. New York: Harper \& Row.

Duda, J. L. \& Treasure, D. C. (2010). Motivational Processes and the Facilitation of Quality Engagement in Sport. In J. M. WILLIAMS (Ed.) Applied Sport Psychology: Personal Growth to Peak Performance (59-80). New York: McGraw-Hill.

Eklund, R., \& Cresswell, S. (2007). Athlete Burnout. In G. TENENBAUM, \& R. EKLUND (Eds.) Handbook of sport psychology (621-641). New Jersey: John Wiley \& Sons.

JARVIS, M. (2006). Sport Psychology. A Student's Handbook. New York: Routledge. 
Lukwu, R. M. \& Guzmán Luján, J. F. (2011). Sport Commitment and Adherence: A Social-Cognitive Analysis. International Journal of Sport Science, 7 (24), 277-286.

Macák, I. \& Hošek, V. (1989). Psychologie tělesné výchovy a sportu. Praha. Štátne pedagogické nakladatel'stvo.

Macková, Z. (2003). Šport ako duševný zážitok. Bratislava: Univerzita Komenského.

RYAN, R. M. et al. (1997). Intrinsic Motivation and Exercise Adherence. International Journal of Sport Psychology, 28 (4), 335-354.

Slepička, P., Hošek, V. \& Hátlová, B. (2009). Psychologie sportu. Praha: Karolinum.

Stadden, S. (2007). The influence of athletic identity, expectation of toughness, and attitude toward pain and injury on athletes' help-seeking tendencies: dissertation thesis Greensboro: The University of North Carolina.

Salmela, J. H. (1994) Phases and Transitions Across Sports career. In D. HACKFORD (Eds). Psycho-social Issues and Interventions in Elite Sport (11-28). Frankfurt Germany: Lang.

Stambulova, N. \& Hanin, Y. (2004). Sport Psychology, Overview. In CH. SPIELBERGER (Eds.) Encyclopedia Of Applied Psychology (463-477). USA: Elsevier Academic Press.

Strauss, A. \& Corbinová, J. (1999). Základy kvalitativního výzkumu. Boskovice: Albert.

Vallerand, R. J. et al. (2003). Les Passions De L'a 'Me: On Obsessive and Harmonious Passion. Journal of Personality and Social Psychology. 85 (4), 756-767.

Vallerand, R. J. et al. (2008). Passion and Performance Attainment in Sport. Psychology of Sport and Exercise. 9, 373-392.

Votík, J. (2011). Fenomény vývoje sportovní kariéry v generačním kontextu Československých fotbalových reprezentantů. Praha: Grada Publishing.

Weiten, W. (2007). Psychology: Themes and Variations. Belmont: Thomson Wadsworth.

Wylleman, P. \& Lavallee, D. (2004). A Developmental Perspective in Transitions Faced by Athletes. In M. WEISS (Eds). Developmental Sport and Exercise Psychology: A Lifespan Perspective (507-527). Morgantown WV: Fitness Information Technology.

\section{Corresponding author:}

Katarína Šimková, Email: 453347@mail.muni.cz 